\begin{tabular}{c|c|c}
\hline \hline & MARINE ECOLOGY PROGRESS SERIES \\
Vol. 215: 37-47, 2001 & Mar Ecol Prog Ser & Published May 31 \\
\hline \hline
\end{tabular}

\title{
Development of sessile marine assemblages on fixed versus moving substrata
}

\author{
T. M. Glasby* \\ Centre for Research on Ecological Impacts of Coastal Cities, Marine Ecology Laboratories, A11, University of Sydney, \\ New South Wales, 2006, Australia
}

\begin{abstract}
Epibiotic assemblages have been shown previously to differ between pontoons and rocky reefs. This may occur for a variety of reasons, one of which is that pontoons move, whereas reefs do not. Effects of movement of the substratum are particularly pertinent to studies involving settlement panels because these experimental units are often suspended from pontoons such that they can move up and down, or attached to ropes such that they can rotate. The development of epibiotic assemblages on panels that were fixed, moved up and down, or rotated, was studied to test hypotheses about the effects of movement on sessile organisms. The covers of barnacles, sponges and ascidians increased greatly with increasing movement and/or rotation of the substratum, whereas species of red and brown foliose algae and tubiculous polychaetes generally decreased with increasing movement and/or rotation of the substratum. In general, assemblages on panels that moved up and down were most similar to those on rotating panels. One of the most obvious differences was the 2 to 3 -fold greater biomass on rotating panels compared to fixed panels, which was attributed to the greater abundance of barnacles. It was concluded that, although movement of a surface can influence the composition of assemblages, this factor on its own may explain only some of the differences reported between pontoons and reefs. Furthermore, the method of deployment of settlement panels was shown to have great effects on the types of assemblages that develop. Differences in water flow were proposed to explain some of the observed patterns, but this idea needs to be investigated further.
\end{abstract}

KEY WORDS: Artificial habitats $\cdot$ Fouling $\cdot$ Epibiota $\cdot$ Movement $\cdot$ Flow $\cdot$ Urban structures $\cdot$ Sampling $\cdot$ Barnacles

Resale or republication not permitted without written consent of the publisher

\section{INTRODUCTION}

The growth of sessile marine organisms on artificial hard substrata has been studied since the early 1900s (e.g. Visscher 1927, Coe 1932, Coe \& Allen 1937). Floating substrata, in particular, were noted to support large abundances of sessile marine organisms (Grave 1933). Subsequently, it became somewhat traditional to study the settlement of these epibiotic (or fouling) organisms by attaching panels to floating rafts or pontoons (e.g. Wisely 1959, Osman 1977, Russ 1977, Sutherland \&

\footnotetext{
*Present address: The Ecology Lab Pty Ltd, 4 Green Street, Brookvale, New South Wales 2100, Australia.

E-mail: tglasby@theecologylab.com.au
}

Karlson 1977, Greene \& Schoener 1982, Hurlbut 1991, Bourget et al. 1994). Another common method of deploying settlement panels is to attach them to ropes suspended from a structure or to ropes anchored to the substratum and held vertically by a float (e.g. Wilson 1925, Graham \& Gay 1945, Mook 1981, Osman 1982, Bingham 1992, Archambault \& Bourget 1999). Thus, the panels can rotate, or at least move considerably, and tend to orientate parallel to the prevailing current. Settlement panels deployed in these ways are clearly quite different from almost all natural hard substrata (except perhaps seagrasses), which would hardly ever move. It is less common that settlement panels are attached directly to, or in positions similar to, natural hard substrata (but see Harlin \& Lindbergh 1977, Keough \& 
Downes 1982, Todd \& Turner 1986, McGuinness 1989). The method of attaching settlement panels could certainly influence the types of assemblages (sensu Underwood 1986) that develop on them. This idea has, however, never been tested in any formal manner.

Continuing urbanization of coastal regions is resulting in floating pontoons and other artificial structures becoming common in waterways. Recent work in Sydney Harbour indicates that assemblages of sessile invertebrates colonising these structures are quite different from those on nearby rocky reefs (Connell \& Glasby 1999, Glasby \& Connell 2001). Assemblages on pontoons were the most distinct - many taxa that were common on pontoons were uncommon on rocky reefs at shallow depths (Connell \& Glasby 1999). Comparisons of epibiotic assemblages on floating surfaces and natural hard substrata in other areas are relatively rare, but there is evidence to indicate that there may be large differences between them (Fuller 1946, Withers \& Thorp 1977).

The reason(s) for differences in assemblages on floating and fixed substrata have not yet been determined. Possibly the most likely explanations are that floating surfaces are constantly near the surface of the water and/or that floating surfaces move whereas natural hard substrata do not. The second possibility was examined in the present study. Clearly, there is the potential for water flow to be very different around surfaces that move compared to surfaces that are fixed. Water flow can influence the settlement and development of many marine invertebrates (e.g. Eckman 1983, Mullineaux \& Butman 1991, Eckman \& Duggins 1993, Mullineaux \& Garland 1993), and so differences in flow between fixed and moving surfaces could cause quite different epibiotic assemblages to develop.

The study described here had 2 aims. First, to test the model that the up and down and side to side movement of pontoons could explain differences in assemblages on pontoons and rocky reefs. Second, to assess the appropriateness of different methods of deployment of settlement panels for testing hypotheses about naturally occurring assemblages. I suggest that assemblages that develop on panels which move in any way (e.g. up and down and/or rotating) tend to be more like those on pontoons than rocky reefs because of the effects of movement. The main prediction being tested therefore, was that surfaces that move up and down like a pontoon would support assemblages similar to those on surfaces that rotate, like settlement panels attached to a rope, and these would be different from assemblages that developed on fixed hard substrata. Assemblages that developed on moving or rotating substrata were predicted to be dominated by taxa similar to those previously sampled on pontoons, while those on fixed substrata should be more like assemblages characteristic of shallow subtidal rocky reefs.

\section{MATERIALS AND METHODS}

Settlement panels and experimental treatments. Experimental structures were set up at 2 sites, $\sim 3 \mathrm{~km}$ apart, on the southern (Chowder Bay; Site 1) and northern (HMAS Penguin; Site 2) sides of Middle Head, Sydney Harbour $\left(33^{\circ} 50^{\prime} \mathrm{S}, 151^{\circ} 15^{\prime} \mathrm{E}\right)$. Both sites are military areas and have similar surrounding habitats, i.e. mainly soft sediments, some seagrasses (Zostera capricorni Ascherson and Halophila ovalis [Brown]), shallow fringing rocky reefs, piers with wooden pilings and slipways that are no longer used. The sites are $\sim 3 \mathrm{~km}$ from the open ocean but protected from direct swell by the headland. Sandstone settlement panels $(15 \times 15 \mathrm{~cm})$ were deployed in each of 3 experimental treatments at each site. The treatments were (1) fixed, (2) moving and (3) rotating panels. All panels were positioned vertically and attached to $1.6 \mathrm{~m}$ long aluminium beams (as in Glasby 1998), which sat 40 to $70 \mathrm{~cm}$ above the sandy seafloor at depths of 2.5 to $3.5 \mathrm{~m}$ below Mean Low Water Springs and were not shaded by jetties, pontoons etc. The panels were bolted firmly to the aluminium beams, but the beams were either fixed, suspended, or designed to rotate, depending on the experimental treatment.

Horizontal beams supporting vertical fixed panels were attached to 2 concrete blocks which were partially buried in the soft sediment (as in Glasby 1998). The blocks were attached with wire to adjacent metal stakes to help support each structure. The fronts of fixed panels faced perpendicular to the direction of the predominant current/surge. The direction of the current was, however, extremely variable at each site, so these panels almost certainly faced parallel to the current at certain times. Beams supporting moving panels were suspended between 2 metal stakes and attached to the stakes by nylon webbing $(15 \mathrm{~cm}$ long $\times 5 \mathrm{~cm}$ wide) and bolts. Concrete blocks were placed at the bases of the metal stakes. Panels faced the same direction as those in the fixed treatment. The beams were made neutrally buoyant by a central, sub-surface float $\sim 1.5 \mathrm{~m}$ above the beam, which was attached to the either end of the beam by rope. Thus, the beams, with panels hanging vertically, moved up and down (no more than $10 \mathrm{~cm}$ ) and, to a limited extent, backwards and forwards. The webbing did not twist easily and so generally prevented the beams from swinging backwards and forward. Beams that supported the rotating panels were made positively buoyant by a large sub-surface float attached as for the moving treatment. The rotating beams were attached to a 
concrete block, which was anchored to a metal stake via a central nylon rope $(40 \mathrm{~cm}$ long) and a stainless steel swivel. The panels hung vertically from the beam, which moved up and down, backwards and forwards to a limited extent, and could also rotate. Rotating panels orientated parallel to the current/surge when water movement was sufficient, but they were relatively slow in responding to changes in currents. On calm days during slack tide, the rotating panels could face any direction.

The floats attached to beams transferred forces due to wave action at the surface down to the moving and rotating panels such that they moved up and down like floating pontoons. Ideally the floats would have sat on the surface, but this was not possible due to theft. The panels in each treatment were accessible to many benthic grazers, but larger grazers were probably less likely to reach the rotating panels because they had to travel up a rope (although urchins were capable of climbing the ropes, pers. obs.). There were, however, few large grazers near the panels because they were situated in a sandy area and at least $20 \mathrm{~m}$ from a rocky reef. Urchins (Heliocidarus erythrogramma [Valenciennes] and Pseudoboletia indiana [Michelin]) occasionally appeared on the concrete blocks and were periodically removed.

There were 5 replicates of each treatment per site, with 1 replicate panel per beam. At each site, the beams were arranged in a $10 \times 10 \mathrm{~m}$ area such that replicates of the same treatment were at least $4 \mathrm{~m}$ apart and replicates of different treatments were at least $2 \mathrm{~m}$ apart. The experiment was run 4 times, with 2 independent start times per site. Experimental structures were lost at 1 site due to storms, so these 2 start times were not the same at each site. Thus, spatial comparisons are confounded by any temporal differences, making it difficult to interpret differences between sites. This does not, however, affect the main comparison among the 3 treatments. The first set of panels was deployed at Site 1 (Chowder Bay) on 7 April (autumn) 1999, the second at Site 1 on 27 April 1999, the third at Site 2 (HMAS Penguin) on 5 May 1999 and the final set at Site 2 on 21 May 1999. All panels were submerged for $29 \mathrm{wk}$.

Sampling and statistical analyses. Upon collection, the panels were suspended and supported in tubs of seawater for transport back to the laboratory, where they were refrigerated at $5^{\circ} \mathrm{C}$ until they were sorted (within $2 \mathrm{~d}$ of collection) under a dissecting microscope. Primary cover (organisms attached directly to the panel) and secondary cover (organisms attached to primary cover) were estimated for sessile organisms on the fronts of panels using 100 regularly-spaced points in a $13 \times 13 \mathrm{~cm}$ grid (i.e. a $1 \mathrm{~cm}$ border around each panel was not sampled to avoid 'edge effects'). Taxa on the fronts of panels, but not under a point were assigned a cover of $0.5 \%$. Species of filamentous algae were not distinguished because often many species were present under a point and it was impossible to allocate the point to just 1 species.

Data for primary and secondary covers of each taxon were summed for univariate (ANOVA) and non-parametric multivariate (PRIMER package) analyses. Percentage cover data for the 2 sites were analysed separately because the experiment was initiated at different times at the 2 sites and there was considerable variability between sites. Data were transformed to arc-sine to remove heterogeneity of variances (Cochran's $C$-test, $\mathrm{p}>0.05$ ) for univariate analyses. One fixed panel was lost from Site 1 (Time 2) and a replicate rotating beam was lost from Site 2 (Times 3 and 4). To maintain balanced univariate analyses, these values were replaced by the mean of the remaining replicates for those treatments at those times and the residual degrees of freedom, mean square estimates and $F$-ratios adjusted accordingly for each taxon (Underwood 1981).

Multivariate data were fourth root transformed and Bray-Curtis similarity matrices calculated. Data were presented graphically using non-metric multi-dimensional scaling (nMDS) ordinations and a stress value indicated how well each ordination satisfied the conditions of its rank similarity matrix. Stress $<0.1$ indicates that the ordination accurately represents the relationships among samples and values $\geq 0.2$ indicate that the ordination may have misrepresented the data (Clarke 1993). One-way analyses of similarities (ANOSIM; Clarke \& Green 1988) and multiple pairwise comparisons were used to test for differences in assemblages among treatments for each time at each site. The Bonferroni procedure was used to adjust significance levels for multiple pairwise comparisons. ANOSIM uses the test statistic $R$, which is calculated using average rank similarities among pairs of replicates within each of 2 groups minus the average rank similarity of replicates between groups, and is scaled to give a value between -1 and 1 (Clarke 1993). Thus, $R \approx 1$ when all pairs of replicates within a group are more similar to each other than they are to pairs of replicates from another group (i.e. groups are different) and $R \approx 0$ when, on average, pairs of replicates within and between groups are equally similar (i.e. no difference between groups). If $R \approx-1$, then pairs consisting of 1 replicate from each group are more similar to each other than are pairs of replicates from the same group (Clarke 1993).

Estimates of biomass. After sorting the first set of panels, it appeared that there was a greater amount of growth on moving and rotating panels than on fixed panels. To test whether this was the case, I estimated 
the biomass on panels for the subsequent 3 times of sampling. Biomass was defined as the dry wt of sessile epibiota on the fronts of panels. After sampling the cover of organisms, panels were soaked in freshwater for $\sim 30$ min and rinsed to remove any mobile organisms (mainly amphipods and polychaetes). Sessile organisms were scraped off the front of each panel using a knife, then sieved on a $500 \mu \mathrm{m}$ mesh. It was not possible to remove all the basal parts of calcareous animals (barnacles and polychaetes), so the biomass on panels with many of these animals would have been slightly underestimated. Care was taken to remove any sandstone which came off the panel on the base of some larger barnacles. The sieved samples were then dried at $70^{\circ} \mathrm{C}$ to a constant weight.

Measurements of water flow. Preliminary results indicated that there were differences between assemblages in the 3 treatments and that these differences were not consistent between sites. To test the model that these patterns corresponded to differences in water flow, 2 techniques were used to estimate water flow among treatments and between sites. First, a Valeport 801 electromagnetic flow meter was used to give an indication of maximal and minimal flows at the depth of the panels at each site. Second, estimates of water flow over the panels in the 3 treatments were made using plaster clods (as in Glasby 1999). Clods were made of plaster of Paris and were roughly cylindrical, with a height of $2 \mathrm{~cm}$, a base diameter of $6 \mathrm{~cm}$ and a top diameter of $4 \mathrm{~cm}$. Initial dry wts of clods ranged between 44 and $50 \mathrm{~g}$. The clods were glued to Perspex cards, soaked in seawater for $30 \mathrm{~h}$, rinsed in freshwater, blotted dry and weighed (Jokiel \& Morrissey 1993). They were then clipped to the fronts of panels (no longer being used for the recruitment experiment) in each treatment ( $\mathrm{n}=3$ per treatment) at each site and left in situ for $48 \mathrm{~h}$. In the lab, the cards were rinsed with freshwater, blotted dry and weighed. Sets of clod cards were deployed on 2 occasions in December 1999.

\section{RESULTS}

\section{Assemblages on settlement panels}

Multivariate analyses involved the comparison of covers of bare space and 54 taxa on panels from different treatments. Taxa included polychaetes, bryozoans, barnacles, bivalves, sponges, ascidians, algae, diatoms and cyanobacteria and most were identified to genus or species. Spirorbid polychaetes were, however, identified only to family and there were 5 unidentified sponges, 2 unidentified bryozoans and 4 unidentified ascidians.
The multivariate analyses indicated that any differences between treatments were less distinct at Site 1 (i.e. Times 1 and 2) than at Site 2 (Table 1). Differences were apparent among treatments at Time 1, but none of the individual pairwise comparisons were significant (Table 1). The most likely differences at this time were between assemblages on fixed and rotating panels and/or between assemblages on moving and rotating panels (Table 1, Fig. 1a), i.e. assemblages on rotating panels appeared different from those on other panels. No such differences were detected for the second time of sampling. At Site 2 (Times 3 and 4), assemblages on fixed panels were consistently different from those on rotating panels and they also tended to be different from assemblages on moving panels (Table 1, Fig. 1c,d). Moving and rotating panels differed only at Time 4 , but, as for most other times, these tended to be the 2 most similar treatments (Fig. 1).

The barnacle Balanus trigonus Darwin was common on most panels and increased in abundance from Times 1 to 4 (Fig. 2a). Significant differences among treatments occurred at each site (Table 2a), with barnacles being least abundant on fixed panels. The cover of barnacles on moving and rotating panels was not different at Site 1, whereas more barnacles covered rotating panels than moving panels at Site 2 (Fig. 2a). Sponges showed similar patterns in that they were significantly more abundant on rotating panels than either fixed or moving panels at Site 1 (Table 2b, Fig. 2b). They were far less abundant at Site 2 (cover $<10 \%$ ) where no differences were apparent among treatments (Fig. 2b).

The colonial ascidian Diplosoma listerianum (Milne Edwards) and the solitary ascidian Styela plicata Lesueur tended to be more abundant on rotating panels than other treatments (Fig. 2c,d). The 1 exception to this pattern was for Time 2 when $D$. listerianum was significantly more abundant on moving panels than on fixed or rotating panels (Table 2c, Fig. 2c). $D$. listerianum was almost non-existent on fixed panels at all times. Green filamentous algae (grouped here as Cladophorales) also tended to be most abundant on rotating panels (Fig. 2e), but only at Site 2 were significant differences detected in this regard (Table 2e).

Red filamentous algae (Ceramiales) consisted primarily of species of Polysiphonia, Ceramium and Griffithsia. Patterns among treatments in the cover of these algae varied among times and between sites (Fig. 2f). Ceramialean algae were significantly less abundant on fixed panels than on either moving or rotating panels at Site 1 for both times (Table 2f), whereas they tended to be most abundant on fixed panels at Site 2, Time 3 (Fig. 2f). Larger red foliose algae (mainly Gelidium spp., Phycodrys australasica Millar and Amphiroa anceps [Lamark]) were significantly more abundant on fixed 
Table 1. Results of multivariate analyses comparing assemblages on panels in 3 treatments for 2 times at each of 2 sites. Significant $\mathrm{p}$ values in bold. Results of pairwise comparisons only given when overall comparison among treatments was significant. Minimum possible $\mathrm{p}$ value for pairwise comparisons (with 126 permutations) is $\mathrm{p}=0.008$

\begin{tabular}{|cccccc|}
\hline Site & Time & Global $R$ & Fixed vs Moving & Fixed vs Rotating & Moving vs Rotating \\
\hline 1 & 1 & $R=0.207, \mathrm{p}=\mathbf{0 . 0 4 7}$ & $R=0.064, \mathrm{p}=0.286$ & $R=0.224, \mathrm{p}=0.079$ & $R=0.248, \mathrm{p}=0.095$ \\
1 & 2 & $R=0.182, \mathrm{p}=0.064$ & - & - & - \\
2 & 3 & $R=0.301, \mathrm{p}=\mathbf{0 . 0 1 5}$ & $R=0.192, \mathrm{p}=0.056$ & $R=0.813, \mathrm{p}=\mathbf{0 . 0 0 8}$ & $R=-0.050, \mathrm{p}=0.579$ \\
2 & 4 & $R=0.591, \mathrm{p}=\mathbf{0 . 0 0 0}$ & $R=0.492, \mathrm{p}=\mathbf{0 . 0 0 8}$ & $R=0.994, \mathrm{p}=\mathbf{0 . 0 0 8}$ & $R=0.381, \mathrm{p}=\mathbf{0 . 0 4 0}$ \\
\hline
\end{tabular}

than moving panels and least abundant on rotating panels at Site 1 (Table 2g, Fig. 2g). A similar, though non-significant pattern occurred at Site 2, but only for Time 3 (Fig. 2g). Brown foliose algae (mainly Ecklonia radiata [C. Agardh] and Dictyota dichotoma [Hudson]) were uncommon on panels, but were also most abundant on fixed panels at Site 1 (Table 2h, Fig. 2h).

Serpulid polychaetes Hydroides elegans (Haswell) were generally most abundant on fixed panels (Fig. 2i). Although patterns were similar at both sites, significant differences among treatments were detected only at Site 1 (Table 2i) where $H$. elegans was significantly (a) Site 1, Time 1

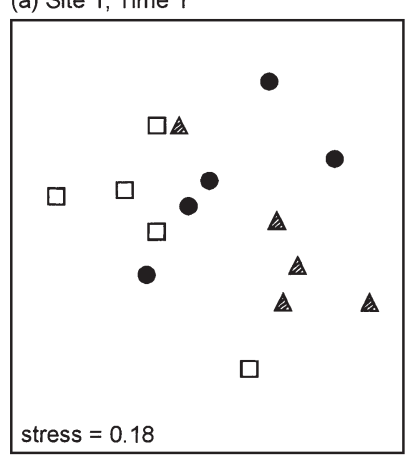

(c) Site 2, Time 3

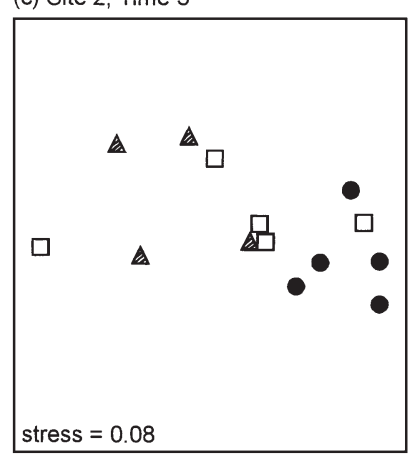

(b) Site 1, Time 2

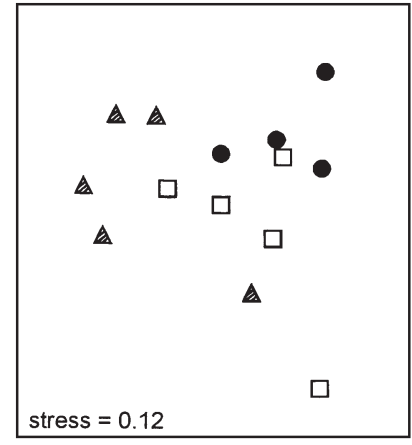

(d) Site 2, Time 4

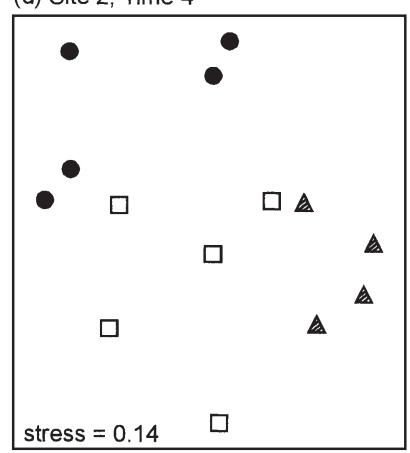

Fig. 1. nMDS ordination comparing assemblages on (-) fixed, (ם) moving and ( $\mathbf{\Delta}$ ) rotating panels at 2 times in each of 2 sites. $\mathrm{n}=5$ for all treatments, except fixed panels at Time 2 and rotating panels at Times 3 and 4 , when $\mathrm{n}=4$. The plot depicts Bray-Curtis rank similarities among replicate samples - the closer together the points, the more similar the assemblages (a) Balanus trigonus

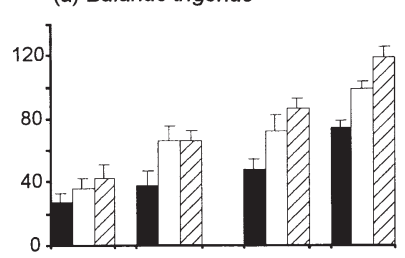

(c) Diplosoma listerianum

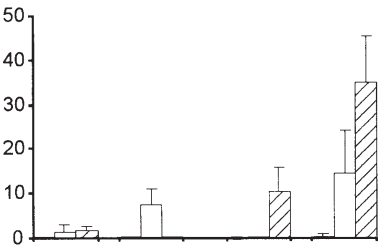

(e) Cladophorales

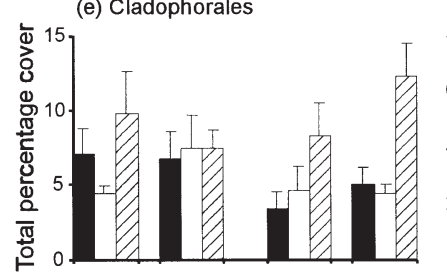

(g) Red Foliose Algae

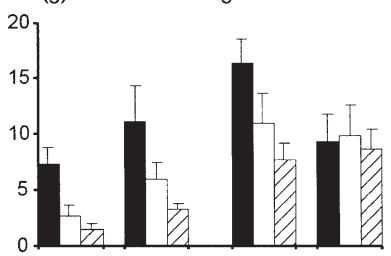

(i) Hydroides elegans

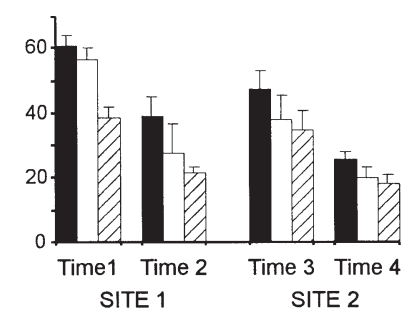

(b) Sponges

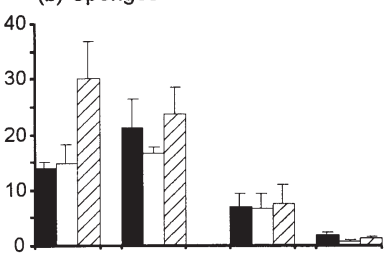

(d) Styela plicata

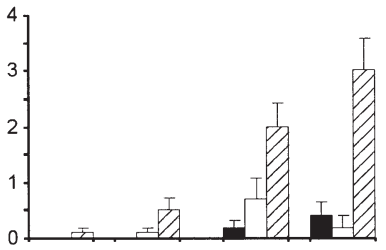

(f) Ceramiales

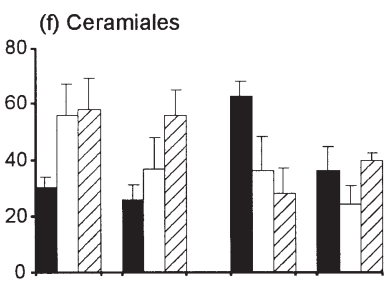

(h) Brown Foliose Algae

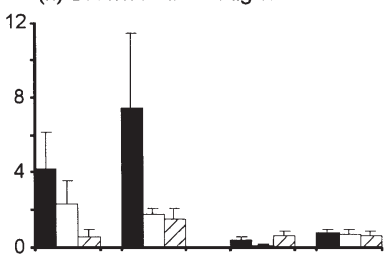

(j) Spirorbids

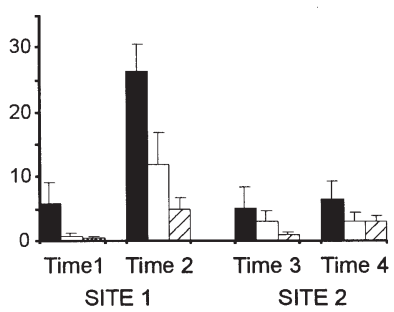

Fig. 2. Percentage cover of taxa $(+\mathrm{SE})$ on panels in 3 treatments ( $\square=$ fixed, $\square=$ moving, $\square=$ rotating) at 2 times in each of 2 sites; $\mathrm{n}=5$, except for fixed treatment at Time 2 and rotating treatment at Times 3 and 4 when $\mathrm{n}=4$. Primary and secondary cover summed, so values $>100 \%$ are possible 
Table 2. ANOVAs comparing covers of taxa on panels in 3 treatments (fixed, moving, rotating) for 2 sampling times at each of 2 sites. Time was a random factor, Treatment was fixed. Significant $p$ values are in bold. When $\operatorname{Ti} \times \operatorname{Tr}$ was non-significant $(p>0.25)$, this term was pooled with the Residual and used as the denominator of the F-test for the factor Treatment. Replicates were lost from certain treatments at each site and analyses have been adjusted accordingly (see text for details). The overall comparison between times was not relevant for testing my hypotheses. Transformations are written above each analysis. ${ }^{*}$ Variances heterogeneous at $\mathrm{p}<0.05_{i}{ }^{* *}$ variances heterogeneous at $\mathrm{p}<0.01$

\begin{tabular}{|c|c|c|c|c|c|c|c|c|}
\hline \multirow[b]{2}{*}{ Source } & \multicolumn{4}{|c|}{ Site 1 (Times 1 and 2) } & \multicolumn{4}{|c|}{ Site 2 (Times 3 and 4 ) } \\
\hline & $\mathrm{df}$ & MS & $F$ & $\mathrm{p}$ & $\mathrm{df}$ & MS & $F$ & $\mathrm{p}$ \\
\hline (a) Balanus trigonus & \multicolumn{4}{|c|}{ No transform } & \multicolumn{4}{|c|}{ No transform } \\
\hline Time & 1 & 3445.41 & 11.85 & - & 1 & 5922.08 & 26.93 & - \\
\hline Treatment & 2 & 1355.58 & 4.70 & 0.019 & 2 & 4279.56 & 20.91 & 0.000 \\
\hline $\operatorname{Ti} \times \operatorname{Tr}$ & 2 & 261.31 & 0.90 & 0.421 & 2 & 36.53 & 0.17 & 0.848 \\
\hline Residual & 23 & 290.84 & & & 22 & 219.90 & & \\
\hline (b) Sponges & \multicolumn{4}{|c|}{ No transform } & \multicolumn{4}{|c|}{ No transform } \\
\hline Time & 1 & 6.77 & 0.08 & - & 1 & 257.40 & 14.04 & - \\
\hline Treatment & 2 & 353.04 & 4.03 & 0.031 & 2 & 1.73 & 0.10 & 0.903 \\
\hline $\operatorname{Ti} \times \operatorname{Tr}$ & 2 & 116.44 & 1.37 & 0.274 & 2 & 0.90 & 0.05 & 0.952 \\
\hline Residual & 23 & 84.98 & & & 22 & 18.33 & & \\
\hline (c) Diplosoma listerianum & \multicolumn{4}{|c|}{ Arc-sine } & \multicolumn{4}{|c|}{ No transform* ${ }^{*}$} \\
\hline Time & 1 & 43.03 & 1.40 & - & 1 & 1274.01 & 7.69 & - \\
\hline Treatment & 2 & 123.83 & 0.95 & 0.512 & 2 & 1291.66 & 3.57 & 0.219 \\
\hline $\operatorname{Ti} \times \operatorname{Tr}$ & 2 & 129.87 & 4.23 & 0.027 & 2 & 362.13 & 2.19 & 0.136 \\
\hline Residual & 23 & 30.68 & & & 22 & 165.64 & & \\
\hline (d) Styela plicata & \multicolumn{4}{|c|}{ No transform ** } & \multicolumn{4}{|c|}{ No transform } \\
\hline Time & 1 & 0.21 & 3.42 & - & 1 & 0.41 & 0.81 & - \\
\hline Treatment & 2 & 0.26 & 2.38 & 0.296 & 2 & 15.11 & 10.73 & 0.085 \\
\hline $\operatorname{Ti} \times \operatorname{Tr}$ & 2 & 0.11 & 1.78 & 0.191 & 2 & 1.41 & 2.79 & 0.083 \\
\hline Residual & 23 & 0.06 & & & 22 & 0.50 & & \\
\hline (e) Cladophorales & \multicolumn{4}{|c|}{ No transform } & \multicolumn{4}{|c|}{ No transform } \\
\hline Time & 1 & 0.10 & 0.01 & - & 1 & 24.30 & 2.29 & - \\
\hline Treatment & 2 & 18.69 & 1.07 & 0.358 & 2 & 116.26 & 10.93 & 0.000 \\
\hline $\operatorname{Ti} \times \operatorname{Tr}$ & 2 & 18.48 & 1.06 & 0.363 & 2 & 11.10 & 1.05 & 0.368 \\
\hline Residual & 23 & 17.35 & & & 22 & 10.60 & & \\
\hline (f) Ceramiales & \multicolumn{4}{|c|}{ No transform } & \multicolumn{4}{|c|}{ No transform } \\
\hline Time & 1 & 512.53 & 1.21 & - & 1 & 569.85 & 1.77 & - \\
\hline Treatment & 2 & 2161.43 & 5.32 & 0.012 & 2 & 1052.48 & 1.14 & 0.468 \\
\hline $\operatorname{Ti} \times \operatorname{Tr}$ & 2 & 218.03 & 0.52 & 0.607 & 2 & 924.16 & 2.87 & 0.078 \\
\hline Residual & 23 & 422.66 & & & 22 & 321.83 & & \\
\hline (g) Red foliose algae & \multicolumn{4}{|c|}{ Arc-sine } & \multicolumn{4}{|c|}{ No transform } \\
\hline Time & 1 & 120.05 & 7.71 & - & 1 & 45.94 & 1.78 & - \\
\hline Treatment & 2 & 197.62 & 13.64 & 0.000 & 2 & 54.39 & 1.27 & 0.440 \\
\hline $\operatorname{Ti} \times \operatorname{Tr}$ & 2 & 2.04 & 0.13 & 0.878 & 2 & 42.80 & 1.66 & 0.213 \\
\hline Residual & 23 & 15.57 & & & 22 & 25.81 & & \\
\hline (h) Brown foliose algae & \multicolumn{4}{|c|}{ Arc-sine } & \multicolumn{4}{|c|}{ No transform } \\
\hline Time & 1 & 48.14 & 1.42 & - & 1 & 0.83 & 4.19 & - \\
\hline Treatment & 2 & 120.99 & 3.80 & 0.036 & 2 & 0.15 & 0.75 & 0.481 \\
\hline $\operatorname{Ti} \times \operatorname{Tr}$ & 2 & 7.07 & 0.21 & 0.814 & 2 & 0.23 & 1.17 & 0.328 \\
\hline Residual & 23 & 34.02 & & & 22 & 0.20 & & \\
\hline (i) Hydroides elegans & & No tra & $\mathrm{rm}^{*}$ & & & No tr & $\mathrm{rm}$ & \\
\hline Time & 1 & 3808.13 & 31.20 & - & 1 & 2599.35 & 21.78 & - \\
\hline Treatment & 2 & 997.73 & 8.37 & 0.002 & 2 & 275.65 & 2.49 & 0.104 \\
\hline $\operatorname{Ti} \times \operatorname{Tr}$ & 2 & 85.73 & 0.70 & 0.506 & 2 & 16.90 & 0.14 & 0.869 \\
\hline Residual & 23 & 122.07 & & & 22 & 119.35 & & \\
\hline (j) Spirorbids & & $\mathrm{Ar}$ & & & & No tr & $\mathrm{rm}$ & \\
\hline Time & 1 & 1472.54 & 33.36 & - & 1 & 11.56 & 0.55 & - \\
\hline Treatment & 2 & 517.11 & 6.78 & 0.129 & 2 & 38.60 & 1.99 & 0.159 \\
\hline $\operatorname{Ti} \times \operatorname{Tr}$ & 2 & 76.31 & 1.73 & 0.200 & 2 & 2.69 & 0.13 & 0.880 \\
\hline Residual & 23 & 44.14 & & & 22 & 20.94 & & \\
\hline
\end{tabular}


more abundant on fixed and moving panels than on rotating panels. No significant differences were detected in the cover of spirorbid polychaetes (Table $2 \mathrm{j}$ ), but, like $H$. elegans, spirorbids tended to be most abundant on fixed panels at each time of sampling (Fig. 2j).

The cover of encrusting and arborescent bryozoans was small (typically $<2 \%$ ) and variable on panels and consequently no differences were apparent among treatments. One species of sabellid polychaete (Branchiomma sp.) was common on the edges and undersides of most panels (i.e. where they were not sampled quantitatively). Species of errant polychaetes were also present on panels, including nereids (Platynereis dumerilli antipoda Hartman, Perinereis sp.), eunicids (Eunice sp., Lysidice sp.), phyllodocids and polynoids. Other mobile invertebrates that were occasionally seen on the panels included the muricid gastropod Bedeva hanleyi (Angas), the seastar Coscinasterias calamaria (Gray) (none larger than $25 \mathrm{~mm}$ across), small unidentified flat worms, crabs, shrimps and tanaids. Importantly, no B. hanleyi or C. calamaria were observed on rotating panels, although the technique for collecting panels was not designed to include mobile species, so it is impossible to be sure that they did not occur on these panels. It does, however, suggest that rotating panels may have been less accessible to small mobile invertebrates than the moving and fixed panels.

\section{Biomass of epibiota}

The biomass of epibiota on the fronts of panels differed significantly among treatments, but the nature of this difference was not consistent for all 3 times of sampling (ANOVA: Time $\times$ Treatment, $F_{4,33}=4.86$, $\mathrm{p}<0.01$ ). Panels that moved and/or rotated had 2 to 3 times more growth on them than fixed panels (Fig. 3). Furthermore, the amount of growth on panels from the fixed and moving treatments was similar at each time of sampling (and between sites), whereas the weight of epibiota on rotating panels increased over time (Fig. 3).

\section{Water flow at sites and around panels}

Water flow was generally low at each of the 2 sites. Current speeds at Site 1 ranged from $0.1 \mathrm{~cm} \mathrm{~s}^{-1}$ (which was the minimum resolution of the sensor) to $9.7 \mathrm{~cm} \mathrm{~s}^{-1}$, while at Site 2 the range was 0.1 to $9.2 \mathrm{~cm} \mathrm{~s}^{-1}$. The mean minimum flow speed (during slack tide) was 2.2 $\pm 0.4 \mathrm{~cm} \mathrm{~s}^{-1}$ at Site 1 and $1.2 \pm 0.2 \mathrm{~cm} \mathrm{~s}^{-1}$ at Site 2 . Mean $( \pm \mathrm{SE})$ maximum current speeds (during ebb tide) were $6.3 \pm 0.8 \mathrm{~cm} \mathrm{~s}^{-1}$ at Site 1 and $7.2 \pm 0.5 \mathrm{~cm} \mathrm{~s}^{-1}$ at Site 2 .

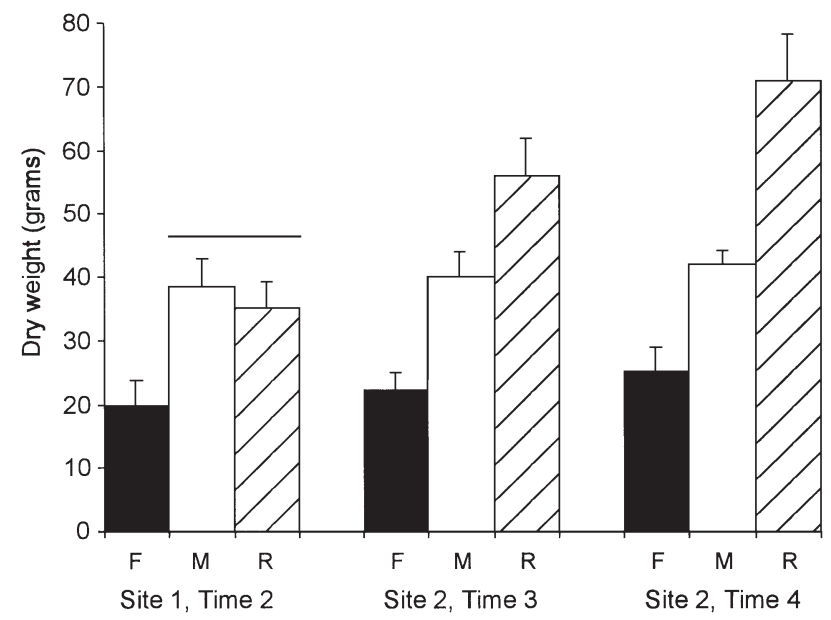

Fig. 3. Biomass (+SE) measured as dry wt $(\mathrm{g})$ on $(\mathrm{F})$ fixed, $(\mathrm{M})$ moving and $(\mathrm{R})$ rotating panels for 3 sampling times. Bar indicates no significant difference between treatments (SNK test on means)

Results from each deployment of clods indicated that the greatest water flow was at Site 2-clods at Site 2 always lost more plaster than those at Site 1 (Fig. 4). Given that the 2 sites were similar depths and had the same types of surrounding habitats (mainly sandy soft sediments), it was assumed that loss of weight from the clods due to scour was similar and that differences in weight were likely to indicate only differences in water flow. Differences in weight could, however, be exaggerated if scour was actually greater where water flow was greatest. Too many clods were lost (due to failure of glue) from certain treatments to allow a statistical comparison among treatments at the 2 times for each site. One analysis was done for the first deployment of clods at Site 2, where significantly more plaster was lost from the rotating treatments compared to the fixed and moving treatments (ANOVA: $F_{2,6}=7.66, \mathrm{p}<0.05$; Fig. 4a). There was a trend for rotating panels to also lose the most plaster for the second deployment at Site 2 (Fig. 4b). Another analysis compared treatments for the second deployment of clods at Site 1, but no significant differences were detected (ANOVA: $F_{2,6}=$ $0.62, \mathrm{p}>0.05$; Fig. $4 \mathrm{~b}$ ) and the same pattern was apparent for the first deployment at this site (Fig. 4a).

\section{DISCUSSION}

These results demonstrate that movement of a hard surface can influence the composition of the subtidal epibiotic assemblage that develops on it over a period of $7 \mathrm{mo}$. The covers of many taxa, especially barnacles, sponges and some ascidians, increased greatly with increasing movement and/or changes in orientation of 
(a) Time 1

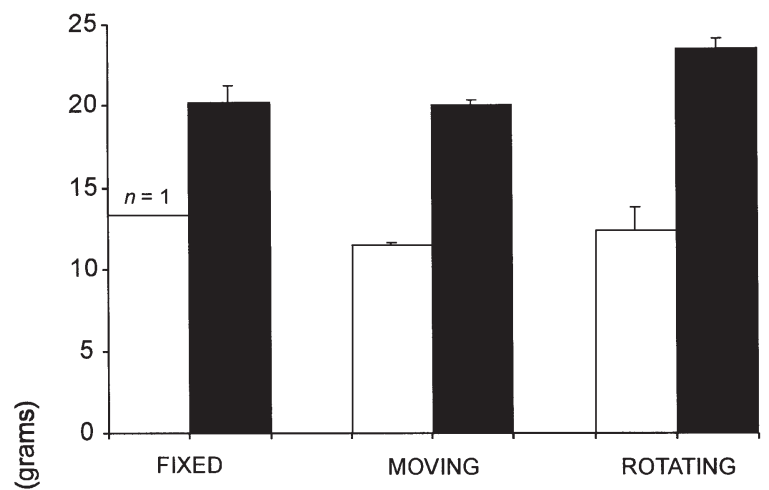

(b) Time 2

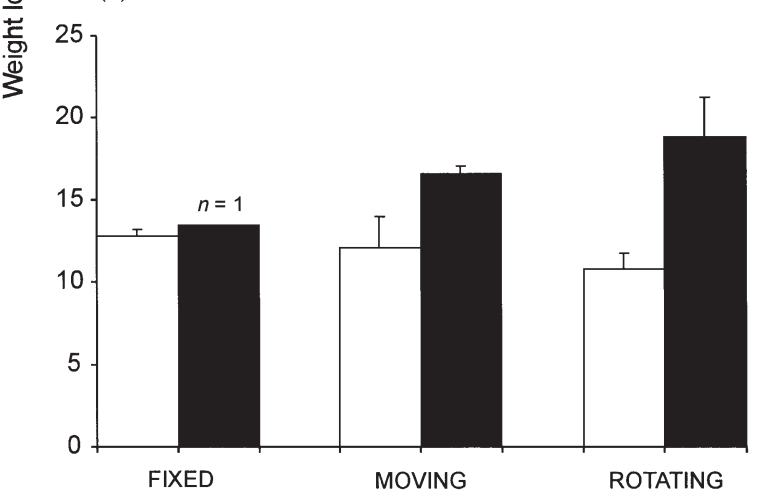

Fig. 4. Weight loss in g (+ SE) of plaster clods on fixed, moving and rotating panels at ( $\square$ ) Site 1 and (ם) Site 2 on 2 occasions. $\mathrm{n}=3$ except where marked otherwise

the substratum. Conversely, species of red and brown foliose algae and tubiculous polychaetes generally decreased with increasing movement and/or rotation of the substratum. Not all the results were as predicted in that the covers of certain taxa were not similar on moving and rotating panels. More often than not, however, differences were apparent between fixed and moving panels and/or between fixed and rotating panels. In general, moving panels were most similar to rotating panels and this interpretation was supported by the multivariate comparisons. The most dramatic result was the 2 to 3 -fold greater biomass on rotating panels compared to fixed panels, which appeared to be driven mainly by the abundance of barnacles. It is possible, however, that different patterns could have emerged if the experiment was initiated at different times of the year when barnacles were not recruiting.

It would appear that effects of movement of the substratum could explain some, but certainly not all, of the differences reported previously between assemblages on pontoons and rocky reefs. Differences in the covers of barnacles, ascidians, serpulids and spirorbids between moving and fixed panels were as predicted in that they were generally comparable to differences that developed between pontoons and reefs in the same area over 7 mo (Connell 2000, Glasby \& Connell 2001). It is difficult, however, to formally compare the results of the present study with past studies of pontoons and reefs because they were done at different times and with different substrata (sandstone vs concrete). Ideally, the same types of panels would have been deployed on pontoons and reefs at the same time as the fixed and moving treatments were deployed, but this was not possible in the present study. Future experiments should also be repeated over longer time periods in order to gain a better understanding of the long-term effects of differences in movement of the substratum. Moreover, testing hypotheses about the interactive effects of movement and various other factors would undoubtedly provide a more comprehensive explanation for differences between assemblages on pontoons and rocky reefs. Effects of shading and proximity to the seafloor almost certainly play an important role in this regard (Glasby 1999), as may other factors such as position relative to the surface of the water. Various epibiotic species, including barnacles and ascidians, can differ greatly in abundance with relatively small differences in depth (e.g. McDougall 1943, Hurlbut 1991, Witman \& Grange 1998).

The differences in covers of some taxa and biomass among treatments demonstrate that the method of deployment of settlement panels can affect the development of assemblages. Furthermore, the nature of these differences may depend on the site and/or time of the experiment. For example, patterns for ceramialean algae among treatments were opposite for Sites 1 and 2, which was possibly a consequence of different flow regimes at the 2 sites. These results give further evidence of the importance of spatial and temporal replication of studies. They also demonstrate that the method of deployment of settlement panels should be justified carefully according to the hypotheses being tested. Specifically, if hypotheses about naturally occurring epibiotic assemblages are being tested using settlement panels, the panels should be deployed in a manner such that they closely mimic the natural surface (see also Glasby 1999). Panels that are suspended from a pier or attached to a rope such that they can rotate would rarely correspond to the movement of any natural surface. This issue needs to be added to the long list of considerations for studies involving settlement panels, such as the size (Jackson 1977, Osman 1977, Keough 1984, Butler 1991) and surface characteristics of the panels (e.g. texture: Pomerat \& Weiss 1946, Crisp \& Ryland 1960, complexity: Bourget et al. 1994, Walters \& Wethey 1996, composition: Raimondi 1988, McGuinness 1989, Anderson \& Underwood 1994).

The most probable cause for differences between fixed, moving and rotating panels relates to differ- 
ences in water flow over fixed versus moving surfaces. Rotating panels could orientate parallel to the prevailing tidal current whereas fixed and moving panels tended to be perpendicular to the current. Water flow (as measured with clod cards) differed among fixed, moving and rotating panels, but only at the site where water movement tended to be greatest (i.e. Site 2, Fig. 4). Nevertheless, differences in the cover of some taxa were still apparent among treatments when differences in water flow were not detected. Thus, the taxa either responded to flows more subtle than those detected in the present study, or the differences among treatments were not a consequence of differences in water flow. As discussed below, results of settlement studies in which water flow has been manipulated suggest that the former explanation may be the most likely, at least for some taxa.

Water flow may affect the settlement of many sessile organisms in a variety of ways (e.g. Crisp \& Stubbings 1957, Foster 1975, Eckman 1983, Pawlik \& Butman 1993, Abelson \& Denny 1997, Osman \& Whitlatch 1998). Flow may also affect the development of biofilms (C.D. Todd pers. com.) which, in turn, can dramatically influence the settlement of epifauna (Todd \& Keough 1994, Keough \& Raimondi 1996, Keough 1998). Mullineaux \& Garland (1993) found that the serpulid polychaete Hydroides dianthus tended to avoid settlement on hard substrata in regions of high shear stress. This corresponds to the results of the present study, which showed that the abundance of $H$. elegans tended to decrease with increasing movement of the substratum, which was presumably associated with increased water flow. Conversely, the cover of barnacles was found to be greatest on rotating panels in the present study. It is quite possible that conditions of water flow around these panels were optimal for the settlement of barnacle cyprids (e.g. Crisp 1976, Mullineaux \& Butman 1991, Sanford et al. 1994).

It is worth noting that percentage cover of epifauna may also have increased due to increasing size of individuals on rotating panels. One study of an intertidal barnacle indicated that the size of adults is not affected by their orientation relative to water flow (Otway \& Underwood 1987), but there is evidence that flow may affect the feeding and growth of some barnacles and other suspension feeding invertebrates (Eckman \& Duggins 1993, Sanford et al. 1994). In fact, Eckman \& Duggins (1993) suggested that the growth of epifaunal species that typically experience relatively weak water flows (such as those in the sites used in the present study) are affected by increases in water flow more so than species that typically experience greater flows.

It is possible that some or all of the patterns documented in this study may have been due to post- rather than pre-recruitment processes. It has often been de- monstrated that post-settlement mortality can drive patterns of abundance of marine biota (reviewed in Hunt \& Scheibling 1997, Gosselin \& Qian 1997). The abundance of some grazers or predators may have differed slightly among fixed, moving and rotating panels. In particular, the gastropod Bedeva hanleyi and the seastar Coscinasterias calamaria were never seen on rotating panels and so could have contributed, either directly or indirectly, to some of the differences among treatments. These predators were not, however, seen regularly nor in large numbers on any panel. Little is known about the feeding habits of $B$. hanleyi, except that it drills mussels and oysters (Ludbrook \& Gowlett-Holmes 1989). It is possible that, like other muricid gastropods, B. hanleyi eats barnacles, which were the most likely prey item on the panels. Barnacle tests were, however, included in estimates of percentage cover, so unless predators totally consumed individuals or caused the tests to fall off the panels, the estimates of cover of this taxon should not have been affected greatly by predators.

Large Coscinasterias calamaria (300 to $400 \mathrm{~mm}$ across) eat mainly small gastropods, bivalves and crustaceans (Keough \& Butler 1979, Jangoux 1982), and evidence suggests that they do not significantly influence the composition of sessile epibiotic assemblages, although they may affect the cover of some colonial ascidians (Keough \& Butler 1979). It seems unlikely, therefore, that in the present study a few very small individuals $(<25 \mathrm{~mm}$ across $)$ could have contributed significantly to the large differences in assemblages among treatments. Furthermore, the access to moving and fixed treatments by mobile invertebrates was quite similar, and yet there were large differences in the covers of various sessile taxa on these panels. Other predators or grazers such as fish (primarily acanthurids, blennids and monacanthids) were common at each site and probably had similar access to all treatments, although the extent to which movement of the substratum could influence fish feeding is not known. Thus, I suggest that any effects of differential predation were minimal and that the effect of movement per se caused the majority of differences among treatments.

This experiment could have been improved by ensuring that invertebrate predators and grazers had the same accessibility to all 3 treatments. Exclusion cages are probably not the best way to achieve this due to their associated artefacts, especially with regards to water flow (Kennelly 1991, Connell 1997). Instead, it would be optimal to make the accessibility of treatments to grazers similar by making the connection between the treatment (e.g. the beams with panels attached) and the seafloor as similar as possible. The structures used in the present study could be modified 
such that the fixed beams attach directly to metal stakes like the moving treatment and the rotating panels could be attached to seafloor with a similarly sized connector.

Differences in movement of the substratum may explain some of the differences described previously between assemblages on pontoons and rocky reefs. Influences of movement of the substratum on sessile epibiota have not been specifically investigated previously, but may also play a role in explaining abundances of epiphytes on seagrasses and macro-algae (Harlin 1980, Keough 1986, Borowitzka et al. 1990, Trautman \& Borowitzka 1999). Many other factors and combinations of influences are also likely to play important roles. Nevertheless, this study has indicated that movement per se can have large influences on the development of sessile epibiotic assemblages. This may be a consequence of altered patterns of water flow, but this idea needs to be investigated further. In general, the more the surface moves and rotates, the more different the assemblage will be from that on a fixed surface. This fact should be considered carefully when deciding upon the method of deployment of settlement panels for testing ecological hypotheses.

Acknowledgements. This research was funded by the Centre for Research on Ecological Impacts of Coastal Cities (University of Sydney). I thank G. Housefield, I. Carlson, M. Sage, T. Davies , P. Archambault, M. Holloway and F. Barros for assistance in the field. A special thanks to G. Housefield for help with designing and constructing experimental structures. Thanks also to P. Archambault, C.D. Todd and A.J. Underwood for much useful discussion and C.J. Glasby for identifying polychaetes. The Defence Estate Organisation and HMAS Penguin kindly allowed me to work at their facilities and I am particularly grateful to K. Shields and Lt. P. Lunt for their assistance. Sandstone was provided by Gosford Quarries Pty Ltd. The manuscript benefited from comments by M. Holloway, M. Lindegarth, A.J. Underwood and 3 anonymous referees.

\section{LITERATURE CITED}

Abelson A, Denny M (1997) Settlement of marine organisms in flow. Annu Rev Ecol Syst 28:317-339

Anderson MJ, Underwood AJ (1994) Effects of substratum on the recruitment and development of an intertidal estuarine fouling assemblage. J Exp Mar Biol Ecol 184:217-236

Archambault P, Bourget E (1999) Influence of shoreline configuration on spatial variation of meroplanktonic larvae, recruitment and diversity of benthic subtidal communities (Erratum to Vol 238, 161-184). J Exp Mar Biol Ecol 241:309-333

Bingham BL (1992) Life histories in an epifaunal community: coupling of adult and larval processes. Ecology 73: $2244-2259$

Borowitzka MA, Lethbridge RC, Charlton L (1990) Species richness, spatial distribution and colonisation pattern of algal and invertebrate epiphytes on the seagrass Amphibolis griffithii. Mar Ecol Prog Ser 64:281-291
Bourget E, DeGuise J, Daigle G (1994) Scales of substratum heterogeneity, structural complexity, and the early establishment of a marine epibenthic community. J Exp Mar Biol Ecol 181:31-51

Butler AJ (1991) Effect of patch size on communities of sessile invertebrates in Gulf St. Vincent, South Australia. J Exp Mar Biol Ecol 153:255-280

Clarke KR (1993) Non-parametric multivariate analyses of changes in community structure. Aust J Ecol 18:117-143

Clarke KR, Green RH (1988) Statistical design and analysis for a 'biological effects' study. Mar Ecol Prog Ser 46: $213-226$

Coe WR (1932) Season of attachment and rate of growth of sedentary marine organisms at the pier of the Scripps Institution of Oceanography, La Jolla, California. Bull Scripps Inst Oceanogr Tech Ser 3:37-86

Coe WR, Allen WE (1937) Growth of sedentary marine organisms on experimental blocks and plates for nine successive years at the pier of the Scripps Institution of Oceanography. Bull Scripps Inst Oceanogr, Tech Ser 4:101-136

Connell SD (1997) Exclusion of predatory fish on a coral reef: the anticipation, pre-emption and evaluation of some caging artefacts. J Exp Mar Biol Ecol 213:181-198

Connell SD (2000) Floating pontoons create novel habitats for subtidal epibiota. J Exp Mar Biol Ecol 247:183-194

Connell SD, Glasby TM (1999) Do urban structures influence local abundance and diversity of subtidal epibiota? A case study from Sydney Harbour, Australia. Mar Environ Res 47:373-387

Crisp DJ (1976) Settlement responses in marine organisms. In: Newell (ed) Adaptations to environment: essays on the physiology of marine animals. Butterworths, London, p 83-124

Crisp DJ, Ryland JS (1960) Influence of filming and of surface texture on the settlement of marine organisms. Nature 185:119

Crisp DJ, Stubbings HG (1957) The orientation of barnacles to water currents. J Anim Ecol 26:179-196

Eckman JE (1983) Hydrodynamic processes affecting benthic recruitment. Limnol Oceanogr 28:241-257

Eckman JE, Duggins DO (1993) Effects of flow speed on growth of benthic suspension feeders. Biol Bull Mar Biol Lab 185:28-41

Foster MS (1975) Regulation of algal community development in a Macrocystis pyrifera forest. Mar Biol 32:331-342

Fuller JL (1946) Season of attachment and growth of sedentary marine organisms at Lamoine, Maine. Ecology 27: $150-158$

Glasby TM (1998) Estimating spatial variability in developing assemblages of epibiota on subtidal hard substrata. Mar Freshw Res 49:429-437

Glasby TM (1999) Interactive effects of shading and proximity to the seafloor on the development of subtidal epibiotic assemblages. Mar Ecol Prog Ser 190:113-124

Glasby TM, Connell SD (2001) Orientation and position of a substratum have large effects on epibiotic assemblages. Mar Ecol Prog Ser 214:127-135

Gosselin LA, Qian PY (1997) Juvenile mortality in benthic marine invertebrates. Mar Ecol Prog Ser 146:265-282

Graham HW, Gay H (1945) Season of attachment and growth of sedentary marine organisms at Oakland, California. Ecology 26:375-386

Grave BH (1933) Rate of growth, age at sexual maturity, and duration of life of certain sessile organisms, at Woods Hole, Massachusetts. Biol Bull Mar Biol Lab 65:375-386

Greene CH, Schoener A (1982) Succession on marine hard substrata: a fixed lottery. Oecologia 55:289-297 
Harlin MM (1980) Seagrass epiphytes. In: Phillips RC, McRoy CP (eds) Handbook of seagrass biology: an ecosystem perspective. Garland STPM Press, New York, p 117-151

Harlin MM, Lindbergh JM (1977) Selection of substrata by seaweeds: optimal surface relief. Mar Biol 40:33-40

Hunt HL, Scheibling RE (1997) Role of early port-settlement mortality in recruitment of benthic marine invertebrates. Mar Ecol Prog Ser 155:269-301

Hurlbut CJ (1991) The effects of larval abundance, settlement and juvenile mortality on the depth distribution of a colonial ascidian. J Exp Mar Biol Ecol 150:183-202

Jackson JBC (1977) Habitat area, colonization, and development of epibenthic community structure. In: Keegan BF, Ceidigh PO, Boaden PJS (eds) Biology of benthic organisms. Pergamon Press, London, p 349-358

Jangoux M (1982) Food and feeding mechanisms: Asteroidea. In: Jangoux M, Lawrence JM (eds) Echinoderm nutrition. A.A. Balkema, Rotterdam, p 117-159

Jokiel PL, Morrissey JI (1993) Water motion on coral reefs: evaluation of the 'clod card' technique. Mar Ecol Prog Ser 93:175-181

Kennelly SJ (1991) Caging experiments to examine the effects of fishes on understorey species in a sublittoral kelp community. J Exp Mar Biol Ecol 147:207-230

Keough MJ (1984) Effects of patch size on the abundance of sessile marine invertebrates. Ecology 65:423-437

Keough MJ (1986) The distribution of a bryozoan on seagrass blades: settlement, growth, and mortality. Ecology 67: 846-857

Keough MJ (1998) Responses of settling invertebrate larvae to the presence of established recruits. J Exp Mar Biol Ecol 231:1-19

Keough MJ, Butler AJ (1979) The role of asteroid predators in the organisation of a sessile community on pier pilings. Mar Biol 51:167-177

Keough MJ, Downes BJ (1982) Recruitment of marine invertebrates: the role of active larval choices and early mortality. Oecologia 54:348-352

Keough MJ, Raimondi PT (1996) Responses of settling invertebrate larvae to bioorganic films: effects of large-scale variation in films. J Exp Mar Biol Ecol 207:59-78

Ludbrook NH, Gowlett-Holmes KL (1989) Chitons, gastropods and bivalves. In: Shepherd SA, Thomas IM (eds) Marine invertebrates of southern Australia. Part II. SA Government Printing, Adelaide, p 504-724

McDougall KD (1943) Sessile marine invertebrates of Beaufort, North Carolina. Ecol Monogr 13:321-374

McGuinness KA (1989) Effects of some natural and artificial substrata on sessile marine organisms at Goleta Reef, Panama. Mar Ecol Prog Ser 52:201-208

Mook DH (1981) Effects of disturbance and initial settlement on fouling community structure. Ecology 62:522-526

Mullineaux LS, Butman CA (1991) Initial contact, exploration and attachment of barnacle (Balanus amphitrite) cyprids settling in flow. Mar Biol 110:93-103

Mullineaux LS, Garland ED (1993) Larval recruitment in response to manipulated field flows. Mar Biol 116:667-683

Osman RW (1977) The establishment and development of a marine epifaunal community. Ecol Monogr 47:37-63

Osman RW (1982) Artifical substrates as ecological islands. In: Cairns J (ed) Artificial substrates. Ann Arbor Science, Michigan, p 71-114

Osman RW, Whitlatch RB (1998) Local control of recruitment

Editorial responsibility: Otto Kinne (Editor),

Oldendorf/Luhe, Germany in an epifaunal community and the consequences to colonization processes. Hydrobiologia 376:113-123

Otway NM, Underwood AJ (1987) Experiments on orientation of the intertidal barnacle Tesseropora rosea (Krauss). J Exp Mar Biol Ecol 105:85-106

Pawlik JR, Butman CA (1993) Settlement of a marine tube worm as a function of current velocity: interacting effects of hydrodynamics and behavior. Limnol Oceanogr 38: $1730-1740$

Pomerat CM, Weiss CM (1946) The influence of texture and composition of surface on the attachment of sedentary marine organisms. Biol Bull Mar Biol Lab 91:57-65

Raimondi PT (1988) Rock type affects settlement, recruitment, and zonation of the barnacle Chthamalus anisopoma Pilsbury. J Exp Mar Biol Ecol 123:253-267

Russ GR (1977) A comparison of the marine fouling occurring at the two principal Australian naval dockyards. Department of Defence, Australia, Melbourne

Sanford E, Bermudez D, Bertness MD, Gaines SD (1994) Flow, food supply and acorn barnacle population dynamics. Mar Ecol Prog Ser 104:49-62

Sutherland JP, Karlson RH (1977) Development and stability of the fouling community at Beaufort, North Carolina. Ecol Monogr 47:425-446

Todd CD, Keough MJ (1994) Larval settlement in hard substratum epifaunal assemblages: a manipulative field study of the effects of substratum filming and the presence of incumbents. J Exp Mar Biol Ecol 181:159-187

Todd CD, Turner SJ (1986) Ecology of intertidal and sublittoral cryptic epifaunal assemblages. I. Experimental rationale and the analysis of larval settlement. J Exp Mar Biol Ecol 99:199-231

Trautman DA, Borowitzka MA (1999) Distribution of the epiphytic organisms on Posidonia australis and P. sinuosa, two seagrasses with differing leaf morphologies. Mar Ecol Prog Ser 179:215-229

Underwood AJ (1981) Techniques of analysis of variance in experimental marine biology and ecology. Annu Rev Oceanogr Mar Biol 19:513-605

Underwood AJ (1986) What is a community? In: Raup DM, Jablonski D (eds) Patterns and processes in the history of life. Dahlem Konferenzen. Springer-Verlag, Berlin, p 351-367

Visscher JP (1927) Nature and extent of fouling of ships' bottoms. Bull US Bureau Fish 43:193-252

Walters LJ, Wethey DS (1996) Settlement and early post-settlement survival of sessile marine invertebrates on topographically complex surfaces: the importance of refuge dimensions and adult morphology. Mar Ecol Prog Ser 137:161-171

Wilson OT (1925) Some experimental observations of marine algal successions. Ecology 6:303-311

Wisely B (1959) Factors influencing the settling of the principal marine fouling organisms in Sydney Harbour. Aust J Mar Freshwat Res 10:30-44

Withers RG, Thorp CH (1977) Studies on the shallow, sublittoral epibenthos of Langstone Harbour, Hampshire, using settlement panels. In: Keegan BF, Ceidigh PO, Boaden PJS (eds) Biology of benthic organisms. Pergamon Press, London, p 595-604

Witman JD, Grange KR (1998) Links between rain, salinity, and predation in a rocky subtidal community. Ecology $79: 2429-2447$

Submitted: May 11, 2000; Accepted: September 29, 2000 Proofs received from author(s): May 7, 2001 